\title{
VARIABILIDADE GENÉTICA DO CARANGUEJO CYCLOGRAPSUS INTEGER H. MILNE EDWARDS, 1837 AO LONGO DO OCEANO ATLÂNTICO OCIDENTAL
}

\author{
Valezio, B.H. ${ }^{1}$; Tamburus, A.F. ${ }^{1}$; Mantelatto, F.L. ${ }^{1,}{ }^{*}$ \\ ${ }^{1}$ Universidade de São Paulo (USP), Faculdade de Filosofia, Ciências e Letras de Ribeirão Preto (FFCLRP), Laboratório \\ de Bioecologia e Sistemática de Crustáceos (LBSC). \\ *Autor correspondente: flmantel@usp.br
}

\begin{abstract}
Estudos sobre a variabilidade genética populacional em crustáceos decápodes têm mostrado diferentes padrões de estruturação gênica em populações de uma mesma espécie. Com base em análises morfológicas e moleculares, pesquisas nesta área buscam entender a dinâmica populacional das espécies e suas variações intraespecíficas. Assim, para o presente estudo estão sendo utilizadas ferramentas - tanto moleculares quanto morfológicas para avaliar a variabilidade da espécie do caranguejo marinho Cyclograpsus integer. Esta espécie apresenta uma distribuição ampla desde a Flórida até o Brasil (do Rio Grande do Norte ao Rio Grande do Sul). Assim, nesta etapa do estudo, a hipótese a ser testada é que não existe estruturação genética ao longo de sua distribuição no oceano Atlântico Ocidental, uma vez que esta é bem abrangente e conta com a presença de potenciais barreiras geográficas. As análises moleculares foram obtidas por meio da amplificação do gene mitocondrial COI. Foram geradas 15 sequências a partir de espécimes advindos do México e dos estados de São Paulo, Pernambuco e Rio Grande do Norte. Junto a estas sequências obtidas, foram adicionadas 3 sequências do GenBank, sendo uma da mesma espécie e outras duas de espécies congêneres, para o alinhamento e construção de uma matriz de distância genética (pairwise distance) e uma árvore por meio do método de Maximum Likelihood. A partir das análises feitas, a hipótese foi confirmada, pois não foi observada estruturação populacional para os espécimes analisados, demonstrando que as potenciais barreiras existentes (correntes marinhas de aguas frias e equatoriais, desague de aguas de rios de grande volume e áreas de ressurgência) não constituem agentes limitadores para impedir fluxo gênico entre as populações analisadas.
\end{abstract}

Palavras-chave: variabilidade genética, estruturação populacional, Cyclograpsus integer, gene mitocondrial.

Financiamento: BIOTA FAPESP (Temático Proc. 2010/50188-8); CAPES/Ciências do Mar II (Proc. 2005/2014 23038.004308/201414); PUB/USP IC. 